\title{
PENYULUHAN KEWAJIBAN MEMILIKI KTP-el DI DESA UJUNG BATU TIMUR BERDASARKAN UNDANG-UNDANG ADMINISTRASI KEPENDUDUKAN
}

\author{
Ardiansah $^{* 1}$, Bagio Kadaryanto ${ }^{2}$, Silm Oktapani ${ }^{3}$ \\ 1, 2,3 Program Studi Ilmu Hukum, Fakultas Hukum, Universitas Lancang Kuning \\ e-mail: ardiansyah2000@yahoo.com
}

\begin{abstract}
Even though the government has enacted Law Number 24 of 2013 concerning Population Administration, in reality many residents are 17 years old who did not have KTP-el. This is because the residents do not understand the rules and sanctions. The method of this activity is lecture. Lecturer as speaker, while and village apparatus as participants. Before the lecture speaks, participants were asked to fill out a pre-test questionnaire. After the lecture and question and answer, participants were asked to fill out the post-test questionnaire. Based on the results of the activity, it shows that the public's understanding of the KTP-el ownership obligations increases. This can be proven by the various questions asked by the participants and the results of the participant questionnaire assessment. Participants have understood the function of KTP-el, the obligation to have KTP-el, sanctions that do not carry KTP-el, and so on. It is recommended that activities like this can be carried out routinely so that village officials better understand the provisions of the Population Administration Law.
\end{abstract}

Keywords - KTP-el, Population, 17 Years

\section{Abstrak}

Meskipun pemerintah telah memberlakukan Undang-Undang Nomor 24 Tahun 2013 tentang Administrasi Kependudukan, namun kenyataannya masih banyak penduduk berumur 17 tahun yang belum memiliki KTP-el. Hal ini disebabkan penduduk belum memahami aturan dan sanksi yang berlaku. Metode pengabdian kepada masyarakat ini dalam bentuk ceramah. Dosen selaku penceramah, sedangkan dan aparatur desa sebagai peserta. Sebelum doen ceramah, peserta diminta mengisi kuisioner pre-test. Setelah materi dan tanya jawab, peserta diminta mengisi kuisioner post-test. Berdasarkan hasil kegiatan tampak bahwa meningkat pemahaman masyarakat mengenai kewajiban kepemilikan KTP-el. Hal ini dapat dibuktikan berbagai pertanyaan yang diajukan peserta dan hasil penilaian kuisioner peserta. Peserta telah memahami fungsi KTP-el, kewajiban memiliki KTP-el, sanksi yang tidak membawa KTP-el, dan sebagainya. Disarankan agar kegiatan seperti ini bisa dilakukan secara rutin agar aparatur desa lebih memahami ketentuan Undang-Undang Administrasi Kependudukan.

Kata Kunci - KTP-el, Penduduk, 17 Tahun

\section{PENDAHULUAN}

Salah satu negara di dunia ini yang memiliki jumlah penduduk yang terpadat adalah Indonesia. Saat ini, Indonesia menempati urutan pertama se-Asia Tenggara. Peningkatan jumlah penduduk terjadi dari tahun ke tahun berdasarkan hasil sensus penduduk (Reza Amin Nugroho, 2017). Sementara itu, Indonesia merupakan salah satu negara yang memiliki jumlah penduduk terbanyak di Asia (Martiyan Ramdani, 2015). Jumlah penduduk Indonesia tahun 2017 mencapai 261 juta. Jumlah tersebut menurut perkiraan Badan Pusat Statistik (BPS) (Tumotounews, 2017)

Pasal 26 ayat (2) Undang-Undang Dasar Negara Republik Indonesia Tahun 1945 menjelaskan pengertian penduduk Penduduk Indonesia adalah Warga Negara Indonesia dan Warga Negara Asing yang bertempat tinggal di Indonesia. Taat dan patuh dengan peraturan yang berlaku 
merupakan kewajiban bagi penduduk yang tinggal di suatu negara. C.S.T. Kansil menjelaskan bahwa setiap negara mempunyai penduduk karena penduduk bermakna orang yang tunduk pada kekuasaan negara dan bertempat tinggal dalam suatu wilayah tersebut (Reza Amin Nugroho, 2017).

Fokus dari segala persoalan pembangunan ialah kependudukan. Penduduk merupakan objek hasil pembangunan dan sekaligus subjek dalam pembangunan (Puji Hardati, 2013). Penduduk adalah objek sekaligus subjek pembangunan dalam kegiatan pembangunan yang berbentuk sektoral ataupun lintas sektoral terarah dan terkait penduduk. Penduduk yang berjumlah besar sangat berarti jika sebagian besar dari mereka dapat berpartisipasi ataupun berkarya dalam pembangunan. Namun sebaliknya dengan jumlah penduduk yang besar akan menjadi beban bila tidak diberdayakan dengan baik bagi pembangunan dan perekonomian (Astried Wulan Sari, 2016). Untuk itu, Manajemen Sumber Daya Manusia merupakan salah satu instrumen penting bagi organisasi untuk mencapai berbagai tujuannya (Jusuf Irianto, 2011). Sumber Daya Manusia yang baik dihasilkan dari kualitas penduduk yang baik. Oleh karena itu, kependudukan menjadi perhatian penting seiring kompleksitas dan dinamika kependudukan yang meningkat.

Pemerintah Indonesua telah mengubah KTP Nasional yang semula masih manual kemudian berubah menjadi Kartu Tanda Penduduk Elektronik (KTP-el) (Anis Dwi Wijayanti, 2015). KTP-el merupakan dokumen kependudukan yang penting bagi setiap warga negara Indonesia. Penerbitan KTP-el adalah bentuk pelayanan yang wajib dilaksanakan pemerintah, karena mudah bagi pemerintah untuk mengatur pelayanan publik, seperti bidang kesehatan, jaminan kesejahteraan sosial, pendidikan, dan lain-lain (Reza Amin Nugroho, 2017).

Pengelolaan pendaftaran penduduk merupakan tanggung jawab pemerintah Kabupaten/Kota, yang mana pelaksanaannya diawali dari Desa/Kelurahan sehingga penduduk sebagai warga negara merasakan mendapatkan pelayanan yang memuaskan. Sebagai salah satu langkah untuk membantu berbagai pekerjaan yang berhubungan dengan pendaftaran kependudukan yang sesuai standar sehingga pemerintah mulai mengadakan program yang dikenal dengan Sistem Informasi Manajemen Kependudukan (SIMDUK) (Mahmuda Pancawisma Febriharini, 2016)

Undang-Undang Nomor 24 Tahun 2013 tentang Administrasi Kependudukan diterbitkan oleh pemerintah bertujuan untuk mewujudkan tertib administrasi kependudukan secara nasional. Dengan demikian, penduduk Indonesia dapat terdata secara resmi. Pasal 63 ayat (1) UndangUndang Nomor 24 Tahun 2013 menyatakan bahwa penduduk Warga Negara Indonesia dan Orang Asing yang memiliki Izin Tinggal Tetap yang telah berumur 17 (tujuh belas) tahun atau telah kawin atau pernah kawin wajib memiliki KTP-el. Berkenaan dengan bunyi pasal ini maka dapat disimpulkan bahwa bagi Warga Negara Indonesia dan Warga Negara Asing yang memiliki izin tinggal tetap dan telah mencapai umur 17 tahun atau telah menikah wajib untuk memiliki KTP-el.

\section{METODE PELAKSANAAN}

Adapun metode pelaksanaan kegiatan Pengabdian Kepada Masyarakat ini ialah penyuluhan hukum. Dengan rincian metode sebagai berikut: 1) ceramah atau penyuluhan dengan cara pemaparan mengenai penduduk yang telah berumur 17 tahun wajib memiliki KTP-el berdasarkan Undang-Undang Nomor 24 Tahun 2013 Tentang Administrasi Kependudukan. 2) Dialog interaktif, dalam hal ini peserta diposisikan sebagai subjek yang dapat memberikan ulasan terkait dengan problematika penduduk yang telah berumur 17 tahun belum memiliki KTP-el. Dialog ini sebagai curah pendapat dari peserta untuk memperoleh masukan berupa persoalan, aspirasi, usulan, gagasan dan solusi. 3) penyebaran kuisioner pre-test sebelum ceramah dan posttest sesudah ceramah bertujuan untuk mengukur tingkat pemahaman masyarakat mengenai KTP-el berdasarkan Undang-Undang Nomor 24 Tahun 2013 tentang Administrasi Kependudukan.

\section{HASIL DAN PEMBAHASAN}

Dari hasil kegiatan penyuluhan hukum mengenai Peningkatan Pemahaman Masyarakat Mengenai Kewajiban Memiliki KTP-el Di Desa Ujung Batu Timur Kabupaten Rokan Hulu Berdasarkan Undang-Undang Nomor 24 Tahun 2013 tentang Administrasi Kependudukan tampak 
meningkat pemahaman peserta baik aparatur desa maupun warga masyarakt mengenai kewajiban memiliki KTP-el. Peningkatan pemahaman masyarakat bisa dibuktikan dengan adanya berbagai pertanyaan yang diajukan peserta kepada pemateri dan hasil jawaban isian kuisioner pre-test dan post-test mengenai Peningkatan Pemahaman Masyarakat Mengenai Kewajiban Memiliki KTP-el Di Desa Ujung Batu Timur Kabupaten Rokan Hulu Berdasarkan Undang-Undang Administrasi Kependudukan.

Kegiatan Pengabdian kepada Masyarakat bidang kajian iptek hukum ini menitikberatkan pada aspek formil dan materil mengenai kepemilikan KTP-el berdasarkan Undang-Undang Administrasi Kependudukan. Kegiatan ini dilaksanakan di ruang pertemuan kantor Desa Ujung Batu Timur Kecamatan Ujung Batu Kabupaten Rokan Hulu pada hari Kamis Tanggal 17 Januari 2019, mulai pukul 10.00 WIB hingga pukul 12.00 WIB. Kegiatan ini dihadiri oleh Camat Ujung Batu Ari Gunadi S.STP, Kepala Desa Ujung Batu Timur Herdi Yanto, Kepala UPTD Disdukcapil Kecamatam Ujung Batu, Bhabinkamtibmas, Ketua Rukun Tetangga, Ketua Rukun Warga, Kepala Dusun Ujung Batu Timur, dan Warga Masyarakat Desa Ujung Batu Timur. Keseluruhan peserta yang hadir sebanyak 21 (dua puluh satu) orang.

Acara diawali sambutan oleh Ketua Tim Pengabdian Kepada Masyarakat Dr. Ardiansah, S.H., M.Ag, M.H., seterusnya sambutan disampaikan oleh Kepala Desa Ujung Batu Timur Herdi Yanto dan sambutan disampaikan oleh Camat Ujung Batu Ari Gunadi S.STP. Pemateri kegiatan Pengabdian kepada Masyarakat kali ini adalah Dr. Bagio Kadaryanto, S.H., M.H. Dr. Bagio Kadaryanto menyampaikan materi tentang Kewajiban Memiliki KTP-el Berdasarkan UndangUndang Nomor 24 Tahun 2013 tentang Administrasi Kependudukan. Pematei menggunakan powerpoint agar mudah dipahami oleh seluruh peserta penyuluhan hukum. Penyampaian materi berlangsung sekitar lebih 30 (tiga puluh) menit.

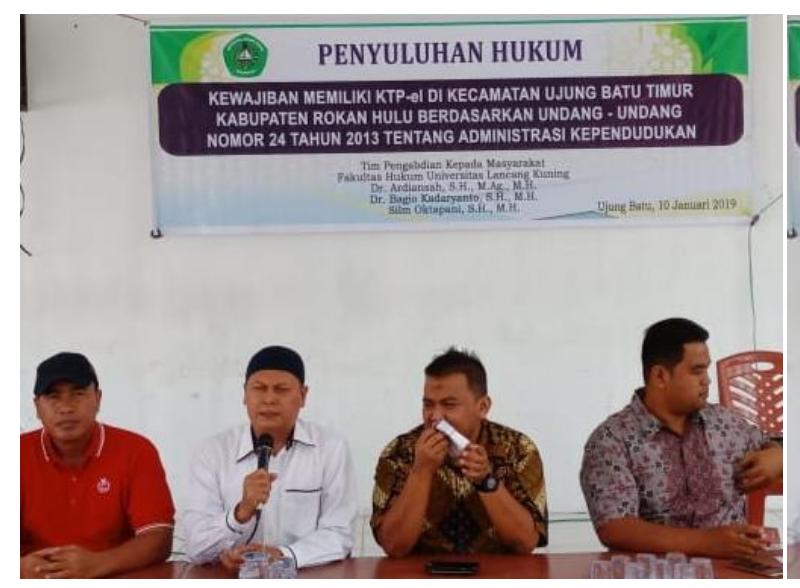

Sambutan Ketua Tim Pengabdian Masyarakat Dr. Ardiansah, S.H., M.Ag., M.H.

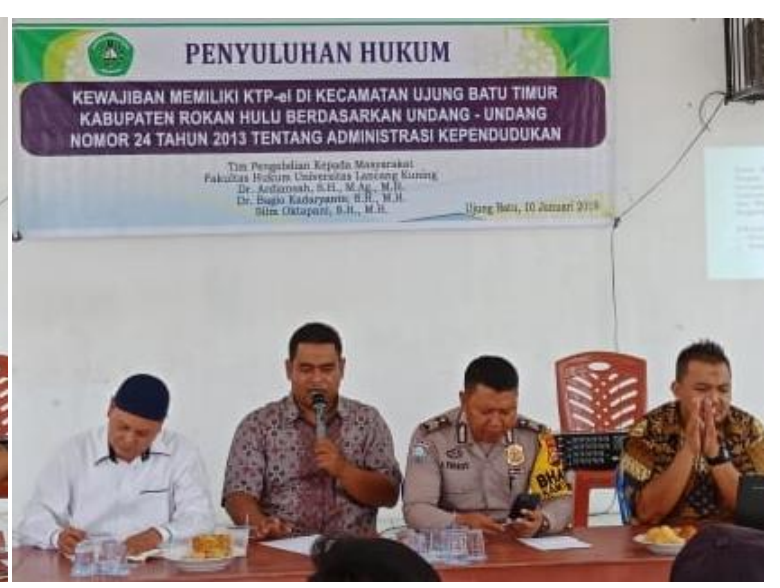

Sambutan Kepala Desa Ujung Batu Timur Herdi Yanto

Setelah pemateri penyampaikan materi, kemudian peserta diberi kesempatan untuk mengajukan pertanyaan yang berkaitan dengan materi penyuluhan hukum. Pertanyaan pertama diajukan oleh Harde Yanto, Kepala Desa Ujung Batu Timur. Harde Yanto dengan kritis bertanya, apakah boleh Warga Negara Asing yang menetap di Ujung Batu boleh membuka usaha (bisnis) dan bagaimana cara mengetahui statusnya tinggal di Ujung Batu?. Selanjutnya, bagaimanakah langkah yang harus ditempuh untuk mengetahui status izin tinggal Warga Negara Asing tersebut. Pemateri, Dr. Bagio Kadaryanto memberikan jawaban bahwa setiap Warga Negara Asing harus memiliki izin tinggal di Indonesia. Untuk mengetahui status izin tinggalnya, maka aparatur pemerintah perlu bekerjasama dan berkordinasi dengan pihak imigrasi untuk mendata dan memeriksa status izin tinggal setiap Warga Negara Asing. Ari Gunadi, Camat Ujung Batu menambahkan jawaban yang telah disampaikan pemateri. Ari Gunadi menjelaskan bahwa Ketua Rukun Tetangga wajib mengetahui status izin tinggal setiap warga masyarakat di wilayahnya. Ketua Rukun Tetangga wajib pula menanyakan bagaimana status izin tinggal Warga Negara Asing 
tersebut. Oleh karena itu, Ketua Rukun Tetangga memiliki peran penting untuk memastikan status warganya.

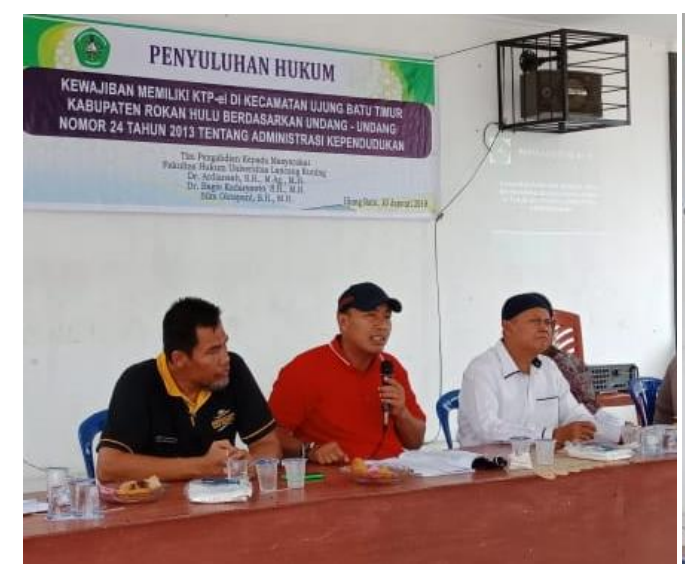

Sambutan Camat Ujung Batu Ari Gunadi S.STP

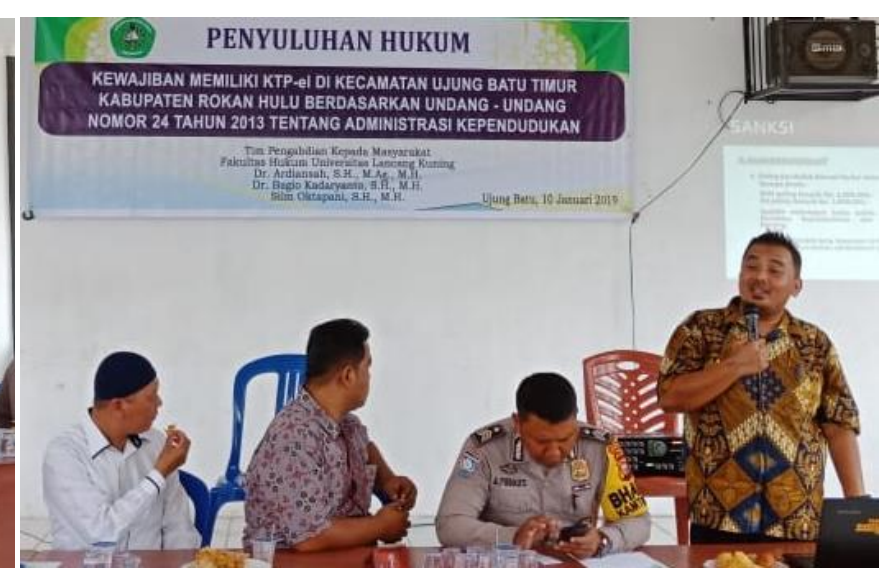

Dr. Bagio Kadaryanto,S.H., M.H Menyampaikan Materi Penyuluhan Hukum

Pertanyaan kedua diajukan oleh Isnawan Ali. Ia bertanya mengenai bagaimana data KTPel yang sudah direkam, namun sampai sekarang belum selesai pembuatan KTPnya. Kemudian agak melenceng, Isnawan Ali menanyakan apa itu KUHP, KUHAP, P21, BAP, SP3, dan PK. Pemateri, Dr. Bagio Kadaryanto memberikan jawaban data KTP-el yang sudah direkam, namun belum selesai pembuatan KTPnya bisa disebabkan berbagai faktor, seperti belum cukup persyaratan, mesin yang rusak, dan lain-lain. Selanjutnya, Dr. Bagio Kadaryanto memberikan jawaban bahwa KUHP (Kitab Undang-Undang Hukum Pidana) adalah kumpulan dari peraturan-peraturan yang berkaitan dengan tindak pidana, KUHAP (Kitab Undang-Undang Hukum Acara Pidana) adalah kumpulan aturan-aturan yang berkaitan dengan bagaimana tata cara pelaksanaan proses beracara dalam hukum pidana, P21 adalah berkas berita penyidikan telah lengkap, BAP adalah Berita Acara Pemeriksaan, SP3 adalah Surat Penghentian Penyidikan Perkara dan PK biasa disebut dengan Peninjauan Kembali adalah suatu upaya hukum yang dapat ditempuh oleh terpidana dalam kasus hukum terhadap suatu putusan yang telah berkekuatan hukum tetap.

Kepala UPTD Disdukcapil Kecamatan Ujung Batu turut menambahkan jawaban pemateri. Kepala UPTD Disdukcapil Kecamatan Ujung Batu menjelaskan adanya permasalahan Disdukcapil Kecamatan Ujung Batu. Bagi masyarakat yang merekam data tahun 2017, maka wajib mengulangi rekam data dikarenakan server pembuatan KTP-el mengalami kerusakan, kemudian perekaman data tahun 2018 diawal tahun blanko tidak tersedia, bulan Agustus tintanya habis dan bulan Oktober baru semuanya lengkap tersedia. Kepala Dinas Disdukcapil Kabupaten Rokan Hulu telah mengintruksikan untuk memperioritaskan bagi pemula dan warga yang memiliki kepentingan yang sangat mendesak untuk memiliki KTP-el. Awal Januari 2019 terjadi masalah teknis dimana alat pembuatan KTP terkena virus dan menunggu petugas dari pusat yang akan datang memperbaiki alat pembuatan KTP, namun untuk perekaman data tetap bisa dilaksanakan.

Pertanyaan ketiga diajukan oleh Mulyono. Ia bertanya apakah ada sanksi apabila berpergian ke kota namun tidak membawa KTP-el yang asli, KTP-el fotokopi atau foto yang disimpan dalam handphone? Dr. Bagio Kadaryanto memberikan jawaban bahwa sebaiknya KTP-el yang asli senantiasa dibawa saat berpergian ke manapun mengingat masih belum adanya aturan yang menyatakan bahwa menunjukkan KTP-el boleh dengan cara KTP-el fotokopi atau foto yang disimpan dalam handphone dibolehkan. Oleh karena itu, setiap warga Negara memastikan membawa KTP-el yang asli untuk mengantisipasi bila berpergian ke kota dan siap bilamana terjadi pemeriksaan dan operasi justisi.

Dari beberapa pertanyaan tersebut tampak peserta sangat tertarik dengan penyampaian materi penyuluhan hukum. Peserta dengan serius menyimak dan mencermati setiap paparan materi kewajiban penduduk memiliki KTP-el. Pada bagian lain, Camat dan Ketua Disdukcapil menyampakan apresiasi dan ucapan terima kasih kepada Tim Pengabdian kepada Masyarakat 
karena telah berkenan melakukan kegiatan penyuluhan hukum ini di daerahnya. Semoga kegiatan seperti ini bisa dilakukan lagi pada masa yang akan datang.
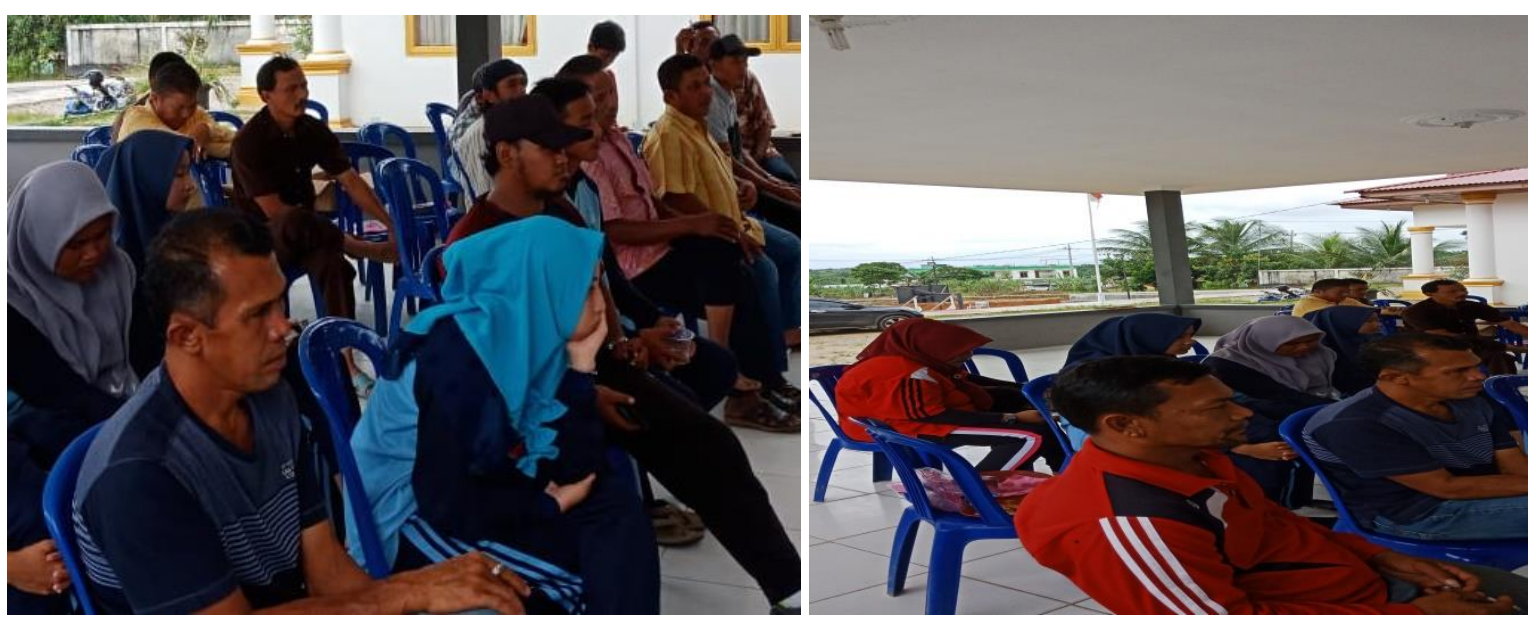

Peserta dengan serius menyimak materi penyuluhan hukum

Sebelum materi penyuluhan hukum disampaikan terlebih dahulu disebarkan kuisioner pre-test untuk diisi peserta dan dikumpulkan sebelum penyampaian materi. Kemudian setelah materi disampaikan kembali disebarkan kuisioner post-test untuk mengukur tingkat pemahaman peserta terhadap materi penyuluhan hukum. Dari hasil kuisioner pre-test dan post-test tampak peningkatan pemahaman peserta dalam menerima materi penyuluhan hukum.

Peningkatan pemahaman peserta penyuluhan hukum dapat terlihat dari hasil pre-test dan post-test sebagai berikut :

\section{Pre Test:}

\begin{tabular}{lllcc}
\hline No & \multicolumn{2}{c}{ Pertanyaan } & Benar & Salah \\
\hline $\mathbf{1}$ & $\begin{array}{l}\text { Penduduk Indonesia adalah Warga Negara } \\
\text { Indonesia dan Warga Negara Asing yang } \\
\text { bertempat tinggal di Indonesia tertuang } \\
\text { dalam........ }\end{array}$ & $67 \%$ & $33 \%$ \\
\hline $\mathbf{2}$ & $\begin{array}{l}\text { Undang-Undang Nomor 24 Tahun 2013 tentang } \\
\text { Administrasi Kependudukan diterbitkan } \\
\text { bertujuan untuk ..... }\end{array}$ & & \\
\hline $\mathbf{3}$ & $\begin{array}{l}\text { Penduduk Warga Negara Indonesia wajib } \\
\text { memiliki KTP-el karena alasan...... }\end{array}$ & $14 \%$ \\
\hline $\mathbf{4}$ & KTP elektronik dikeluarkan karena alasan ... & $86 \%$ & $0 \%$ \\
\hline $\mathbf{5}$ & $\begin{array}{l}\text { Setiap penduduk yang dengan sengaja memiliki } \\
\text { KTP lebih dari satu dipidana penjara paling } \\
\text { lama.... }\end{array}$ & & \\
\hline
\end{tabular}

Pos Test:

\begin{tabular}{lllcc}
\hline No & \multicolumn{2}{c}{ Pertanyaan } & Benar & Salah \\
\cline { 3 - 5 } $\mathbf{1}$ & $\begin{array}{l}\text { Penduduk Indonesia adalah Warga Negara } \\
\text { Indonesia dan Warga Negara Asing yang } \\
\text { bertempat tinggal di Indonesia tertuang } \\
\text { dalam......... }\end{array}$ & & \\
\hline $\mathbf{2}$ & $\begin{array}{l}\text { Undang-Undang Nomor 24 Tahun 2013 tentang } \\
\text { Administrasi Kependudukan diterbitkan } \\
\text { bertujuan untuk ...... }\end{array}$ & & \\
\hline
\end{tabular}


DINAMISIA - Jurnal Pengabdian Kepada Masyarakat Vol. 2, No. 2 Desember 2018, Hal. 328-334

\begin{tabular}{clcc}
\hline $\mathbf{3}$ & $\begin{array}{l}\text { Penduduk Warga Negara Indonesia wajib } \\
\text { memiliki KTP-el karena alasan...... }\end{array}$ & $100 \%$ & $0 \%$ \\
\hline $\mathbf{4}$ & KTP elektronik dikeluarkan karena alasan ... & $90 \%$ & $10 \%$ \\
\hline $\mathbf{5}$ & $\begin{array}{l}\text { Setiap penduduk yang dengan sengaja memiliki } \\
\text { KTP lebih dari satu dipidana penjara paling lama }\end{array}$ & $81 \%$ & $19 \%$ \\
\hline
\end{tabular}

Berdasarkan evaluasi melalui sebaran kuisioner dari jawaban peserta terlihat bahwa secara keseluruhan peserta telah meningkat pemahaman peserta terhadap materi yang disampaikan dan bertambahnya wawasan tentang Kewajiban Memiliki KTP-el Berdasarkan Undang-Undang Nomor 24 Tahun 2013 tentang Administrasi Kependudukan. Peningkatan pemahaman peserta terlihat dari jawaban peserta yang sebagian besar memilih jawaban Penduduk Indonesia adalah Warga Negara Indonesia dan Warga Negara Asing yang bertempat tinggal di Indonesia tertuang pada Pasal 26 (2) UUD NRI Tahun 1945, tertib administrasi kependudukan adalah yang menjadi tujuan dari Undang-Undang Nomor 24 Tahun 2013 tentang Administrasi Kependudukan, penduduk Warga Negara Indonesia yang telah berumur 17 tahun wajib memiliki KTP-el, dengan alasan rusak atau hilang maka KTP-el dapat diterbitkan dan setiap penduduk yang memiliki KTP lebih dari satu dapat di pidana selama 2 tahun penjara.

Berikut ini adalah dokumentasi pada saat pelaksanaan Pengabdian Kepada Masyarakat yang dilakukan Tim dari Fakultas Hulum Universitas Lancang Kuning di Desa Ujung Batu Timur Kecamatan Ujung Batu Kabupaten Rokan Hulu.

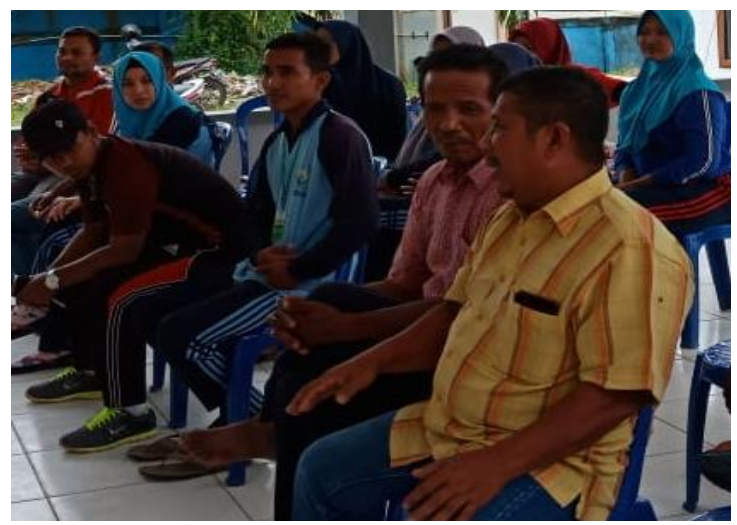

Peserta bertanya kepada pemateri

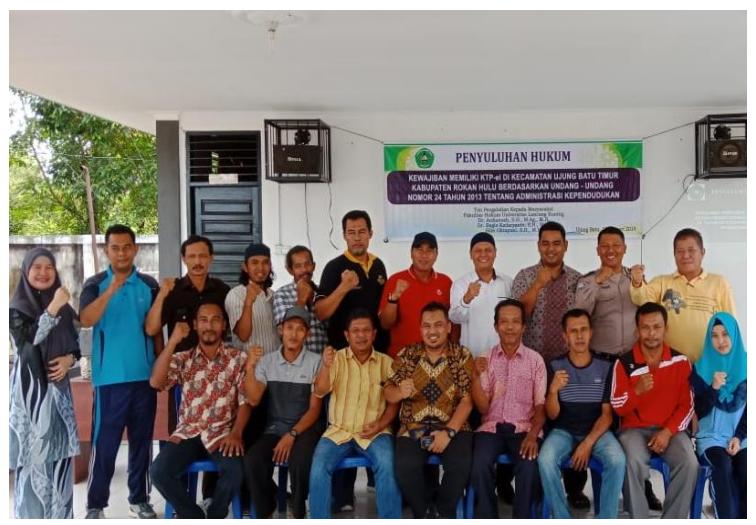

Foto bersama Tim Pengabdian dan peserta

\section{KESIMPULAN}

Setelah dilaksanakan kegiatan pengabdian kepada masyarakat, maka dapat disimpulkan bahwa meningkat pemahaman peserta mengenai fungsi KTP-el yang merupakan identitas diri yang berlaku nasional sehingga masyarakat tidak perlu membuat KTP lokal, meningkat pemahaman peserta mengenai kewajiban penduduk berumur 17 tahun memiliki KTP-el, meningkat pemahaman peserta mengenai tujuan diterbitkannya KTP-el adalah sebagai tertib administrasi kependudukan, dan sebagainya. Selain itu, peserta memperoleh wawasan baru mengenai adanya sanksi administrasi bagi penduduk yang tidak membawa KTP-el yang terjaring razia justisi saat berpergian ke kota dan adanya sanksi pidana bagi penduduk yang memiliki KTP-el ganda.

\section{SARAN}

Kegiatan penyuluhan hukum tentang kewajiban memiliki KTP-el Berdasarkan UndangUndang Nomor 24 Tahun 2013 Tentang Administrasi Kependudukan agar dapat dilakukan secara rutin, sebisanya dilakukan minimal tiap setahun sekali di berbagai daerah. Agar aparatur desa yang belum memahami Undang-Undang Nomor 24 Tahun 2013 Tentang Administrasi Kependudukan dapat lebih memahami, dikarenakan aparatur desa ini yang berhadapan langsung dengan warganya dan dapat menjelaskan tentang pentingnya Kartu Tanda Penduduk. 


\section{UCAPAN TERIMAKASIH}

Tim Pengabdian kepada Masyarakat mengucapkan terimakasih kepada Dekan Fakultas Hukum Universitas Lancang Kuning, Ketua Lembaga Penelitian dan Pengabdian kepada Masyarakat Universitas Lancang Kuning, Camat Ujung Batu, Kelapa Desa Ujung Batu Timur, Ketua Rukun Tetangga, Ketua Rukun Warga Ujung Batu Timur, Warga Desa Ujung Batu Timur dan seluruh pihak yang telah terlibat dalam terselenggaranya kegiatan Pengabdian kepada Masyarakat ini.

\section{DAFTAR PUSTAKA}

[1] Nugroho, Reza Amin, Isharyanto dan Hartriwiningsih, 2017, "Evaluasi Administratif Pemerintah Kabupaten/Kota Dalam Penerbitan KTP Elektronik Berdasarkan Undang-Undang Nomor 24 Tahun 2013 Tentang Administrasi Kependudukan”, Jurnal Pascasarjana UNS, Vol. V No. 1, Januari-Juni.

[2] Ramdani, Martiyan, 2015 "Determinan Kemiskinan di Indonesia Tahun 1982-2012", Jurnal Economic Development Analysis Journal, Vol. 4, No. 1.

[3] TUMOUTOUNEWS.Com.,10/09/2017,http://tumoutounews.com/2017/09/2010/jumlahpenduduk-indonesia-tahun-2017, diakses pada tanggal 30 Oktober 2018.

[4] Hardati, Puji, 2013, "Pertumbuhan Penduduk Dan Struktur Lapangan Pekerjaan Di Jawa Tengah”, Jurnal Forum Ilmu Sosial, Vol. 40 No. 2, Desember 2013.

[5] Sary, Astried Wulan, 2016, "Komunikasi Penyuluhan Administrasi Kependudukan Terhadap Pemahaman UU No 24 Tahun 2013 dan Tingkat Partisipasi Masyarakat Kecamatan Binjai Utara Kota Binjai”, Jurnal Komunikasi Islam : Jurnal Ilmu Komunikasi dan Kajian Islam, Vol. 3 No. 3.

[6] Irianto, Jusuf, 2011, "Manajemen Sumber Daya Manusia Sektor Publikdi Indonesia: Pengantar Pengembangan Model MSDM Sektor Publik", Jurnal Masyarakat, Kebudayaan dan Politik, Vol. 24, No. 4.

[7] Wijayanti, Dwi Anis, 2015, "Implementasi Kartu Tanda Penduduk Elektronik (KTP-el) Di Kantor Kecamatan Sawahan Kota Surabaya", Jurnal Publika, Vol. 3, No. 2.

[8] Febriharini, Pancawisma Mahmuda, 2016, "Pelaksanaan Program eKTP Dalam Rangka Tertib Administrasi Kependudukan”, e- jurnal Serat Acitya, Vol. 5 No. 2. 